2019-02-21

National Menace: Mediating

\title{
Homo/sexuality and Sovereignty in the Polish National/ist Discourses
}

\section{Kulpa, Robert}

http://hdl.handle.net/10026.1/13065

10.1080/17405904.2019.1584578

Critical Discourse Studies

Taylor \& Francis (Routledge)

All content in PEARL is protected by copyright law. Author manuscripts are made available in accordance with publisher policies. Please cite only the published version using the details provided on the item record or document. In the absence of an open licence (e.g. Creative Commons), permissions for further reuse of content should be sought from the publisher or author. 
Kulpa, Robert, "National menace: mediating homo/sexuality and sovereignty in the polish national/ist discourses", in: Critical Discourse Studies (accepted manuscript).

Please check my other publications at: ORCID, ResearchGate, Academia.edu

DR ROBERT KULPA, UNIVERSITY OF PLYMOUTH,

\section{National MenaCe: Mediating Homo/SEXUALITY AND SOVEREIGNTY IN THE POLISH NATIONAL/IST DISCOURSES}

\section{In: CRitical Discourse Studies, AcCePted: 06/12/2018}

\section{Abstract:}

The bio-political discourses of nationhood and homo/sexuality burgeon geo-culturally and historically, and this article presents a case-study of Poland post-2004 EU enlargement. Focused on the (televised) presidential media orchestrations of the 'EU and homosexual menace' and parliamentary resolutions, the tensions between nationhood and sexuality are analysed through the prisms of dislocation, surplus, rhetoric of fear and antagonism. The presented argument: (1) discusses the complex simultaneity of discursive relations (rejection and dependency, flagrancy and obscurity, desire and abjection) spanning political and cultural narratives; (2) accentuates the evocative role of the emotive repertoire of media strategies deployed in the political and cultural 'sex wars' over the notion of 'sovereignty' in the post2004 Poland and 'EUrope'; (3) underlines 'discourse consciousness' of the populist political institutions.

\section{Keywords:}

homosexuality and sovereignty, sexual nationalism, political homophobia, rhetorical fear, cultural dislocation, EUrope, Polish nationalism, politics of sexuality, cultural narratives, representations of nationhood. 


\section{Introduction}

The national/ist biopolitics of citizenship and homo/sexualities are manifold, from rejection to inclusion, from homophobia to homonationalism, from prosecution to institutionalization, burgeoning geographically and historically (among numerous others: G. Brown and Browne 2016; Downing and Gillett 2011; Hayes 2000; Kulpa and Mizielinska 2011; Parker et al. 1992; Stychin 1998). In this article, I present the snapshot case of (post-1989) Poland immersed in 'moral panics' atmosphere around the 2004 EU enlargement, at the moment of heated debates about the 'EU constitution' and its failure (ca. 2007). This time period seems a particularly fertile for considerations of national and sexual identities and discourses at the backdrop of debates on sovereignty and the 'idea of Europe'. The 2004 EU enlargement was widely celebrated as the Central-Eastern European (CEE) final 'return to Europe' (from the implied 'historical fridge' of the state socialism). However, soon after the anxieties spread across the EUrope $^{1}$, populated by the possibility of the so-called 'EU Constitution' and ever-greater unification (and feared possible hegemony) of the EU as a federal state rather than supranational coalition. This legislative possibility had eventually failed, and the unthreatening substitute 'Treaty of Lisbon' has been adopted (2007). Thus the early years of $21^{\text {st }}$ century spawned the national and EUropean debates about the sovereignty and the relevance of national identities in the trans-national world. This resonated particularly well with publics in Poland and CEE, which worried about the young (national) democracies and (supra-national) political hegemonies (since the wounds have not yet healed after the fall of the 'Iron Curtain' (Barrington 2006; Shiraev and Shlapentokh 2002).

\footnotetext{
${ }^{1}$ I write EUrope to highlight the hegemonic pull that the EU bears over the idea of '(new) Europe', narrowing down in common imagination the geographical and cultural diversity of Europe to the selected few European nation-states (cf. the use of Europe and EUrope in: Kulpa (2014).
} 
Against that backdrop, not unusually, the political has been re-routed through media-cultural discourses. For example in Poland, Graff (2009) observed the rise of 'moral panic' around gender, notably in the lamentable discourse of 'crisis of masculinity', and Hall (2017) pointed out to the rise of debates about 'reparative therapy' ('converting' to heterosexuality) among Catholic church representatives and groups, broader conservative audiences, and media outlets. Both authors identify such discursive intensification (and subsequent fadeouts) as sublimations of the anxieties around the EU enlargement in 2004 and later. This article engages in dialogue with the previous scholarship and hopes to further enrich academic debates by identifying homo/sexuality, as well as gender, as the important reference point of the political discourses about the (political and cultural) sovereignty in the enlarged EUrope. The driving question is how the nation-state's discursive framing of homosexuality is orchestrated and communicated by the late Polish President Lech Kaczyński in his live TV broadcast of the "Address to the Nation' (17.03.2008) ${ }^{2}$ and in the Parliament's resolution 'On the Sovereignty of Polish Law in the Matter of Morality and Culture' (M.P. nr 19, poz. 290).

The article deploys the methodologies of qualitative case study approach as drawn from the social sciences and cultural studies disciplines, where it is argued that in order to understand processes and structures, it is important to explore as well the singular events/cases as evidencing aspects of wider frameworks (cf. e.g. Berger 2016; Yin 2009). This is achieved through textual and visual content analysis (Denzin and Lincoln 2005, 869-87; Pink, Kürti, and Afonso 2004; Rose 2001) as suitable techniques of studying media. This methodology is theoretically grounded in the critical studies of discourse and outline of discursive politics elaborated by Ernesto Laclau and Chantal Mouffe (2001; Laclau 2005; Mouffe 2005; Smith 1998). This particular framework was chosen for it addresses the fluidity and processuality of the political change, which is at the core of the analysed case. Andersen (2003, VI) captured 
that well, writing that for Laclau: "[d]iscourse (...) is a structural totality of differences that is a result of an articulatory practice. The totality is, however, never fully achieved. Discourse is a never-completed fixation process that takes place through articulation within a field of discoursivity with drifting relations".

Furthermore, it is important to study political rhetoric, as it influences the cultural and institutional politics on the national and trans-national scales (Eshbaugh-Soha 2010; Lu and Ahrens 2008), and it is a core aspect of the post-communist 're-creation of the nation' politics (Ryazanova-Clarke 2008). Additionally, while Wodak (2015) and Cap (2017) stress the role of fear in populist discourses, Henderson (2006) and Goussios et al. (2014) emphasise the importance of all the affective aspects of the presidential speeches, noting that the study of emotions as the discursive tools of political communication has only begun to develop in political science. This 'affective turn' is also true for critical discourse studies, which so far has been "largely underpinned by a Habermasian idea of a rational subject/speaker" (Milani 2015, 330). The chosen case study TV broadcast sits well among these debates: Kaczyński’s 2008 speech is imbibed with the evocative, affective references to the EU, Germany, and homosexuality passionately framed as threat, breaking the neutral decorum of genre in political communication. As such, this article may also offer more historical grounding for the recent developments in Polish political discourses, and the role of 'communicating threat' and its strategic deployments.

On the wave of the growing critical scholarship on the hegemonic dominance of the Anglophone case studies in the wide field of gender and sexuality studies (G. Brown and Browne 2016), this article's aspiration is to contribute to the young but growing literature on homosexuality and nationhood in the particular geo-cultural context of CEE. This analysis contributes valuable (empirical) case study in historical-sociological perspective that helps understanding of the current politics and rise of the right-wing political populism in (Central- 
Eastern) Europe, which "fuelled the wider undermining of key norms and values of liberal societies including issues of gender, ethnic, religious and cultural diversity and equality" (Krzyżanowski and Ledin 2017, 567). This article is evidencing the historical continuum and meticulous orchestration of a sustained media-political campaigning that twist matters of gender and sexuality to various political needs and gains, well evidenced in the conservativereligious backlash (held under the banners of 'gender ideology' and 'homosexual propaganda') tolling across Poland, European continent and elsewhere (Kuhar and Paternotte 2017; Graff and Korolczuk 2017).

Furthermore, the official live Addresses to the Nation in the public media are rare in Polish political culture (aside from the yearly traditional New Year's speech), reserved for the moments of the extraordinary importance ${ }^{3}$. As such, the chosen case should be seen as a cultural 'media event' of special significance for public culture and discursive power. Additionally, the broadcast brought about a wave of criticisms from numerous public actors and media outlets (gazeta.pl 2008), leading eventually to the removal of the recording form the official presidential media archives ${ }^{4}$ (which otherwise collect all other public appearances, speeches, media interviews, and photo galleries). As discursive silences and omissions are as 'telling' as words and images, this act of 'intentional forgetting' of an event, which was given an extraordinary prominence in the first place, only further highlights the suitability of the chosen case for analysis.

Finally, a decade after this (media) event, one is also able to offer a historical-cultural perspective that lays grounds for the analysis of political changes around public media services in Poland occurring since 2015. Particularly, this analysis may help in understanding the 2016

\footnotetext{
${ }^{3}$ E.g. the infamous Address of Gen. Jaruzelski's introducing state of emergency in 1981, which eventually lead to the consolidation of the Solidarity Movement, and the subsequent fall of the state socialism.

${ }^{4}$ Http://www.prezydent.pl (accessed 25.08.2017).
} 
'hijacking of the public TV and radio' by the populist government (Chołodowski 2017), by turning the public service broadcasters into 'national(ist) media'. This is as much figurative as it is literal: (1) involving the institutional renaming to embrace the word 'narodowe' ('national') in lieu of the previous 'public' descriptor (Kublik 2015); (2) as well as the sweeping personnel purges at the frontline and in the backrooms of the TV and radio channels, committees, and advisory boards (Kublik 2016).

In what follows, I will first present the national and European contexts foregrounding the analysis, which has been split into three sequences: the first one looks at how the 'imagined community' of a nation is performatively pulled together; the second one examines the projections and rhetoric of 'fears and threats'; while the third sequence analyses the emotive mediation of the 'enemy' in the presidential speech.

\section{National and EUropean Contexts}

The EU stance on issues relating to national cultures and traditions of its member states is proclaimed to be non-interventionist, securing national sovereignties ${ }^{5}$. However, the picture is more complicated. Although EU laws do not regulate e.g. women's rights to safe and informed abortion across all member states, there are nevertheless certain policies that do intervene and standardise individual and group identities and bodies in other respects. For example, EU Directives on: equal treatment with the focus on gender (2006/54/EC), on racial equality (2000/48/EC), and on equal treatment in employment and occupation, with a focus on religion, belief, gender, sexuality, disability and age (2000/78/EC). In this light, it is perhaps not surprising that attitudes towards the EU in Poland, especially from the more conservative sides, have been mixed and sceptical (as they were and are in many other countries, of course). The 2003 Polish Sejm (lower chamber of the Parliament) resolution 'On the Sovereignty of Polish

\footnotetext{
${ }^{5}$ http://eur-lex.europa.eu/summary/glossary/acquis.html (accessed 25.08.2017).
} 
Law in the Matter of Morality and Culture' (M.P. nr 19, poz. 290) is an example of just such uneasiness arising in the eve of joining the EU. The fact that it is probably the shortest ever parliamentary resolution - it consists only of one sentence! - also highlights the importance of the 'rhetorical fear' and uncertainness experienced by Polish MPs, who felt the need to have such a resolution passed. It reads:

Heading towards the integration with other European countries within the structures of the European Union, and in the face of the referendum about Polish membership in the Union, the Sejm of the Republic of Poland declares that Polish law concerning the moral order of the social life, the dignity of the family, marriage and upbringing, and the protection of life - is not [and shall not be] a subject of the international regulations. ${ }^{6}$

In its mostly declarative character, the resolution has little bearing on the actual policies and remains mostly a rhetorical, if nonetheless significant, political tool. How can we read it? The pre-accession resolution tells us about the looming sense of the fear and possible clashes between Poland and the EU, in the matter of values and attitudes. Specifically, we learn that the Polish 'moral order of social life, the dignity of the family, marriage and upbringing, and the protection of life' might be under siege by the (secularised, presumably amoral) EU forces. To decode this bundle of references, one needs to refer to a particular discursive matrix developed in Poland in the early 1990s on bodies, sex, gender, and sexuality; a morally charged language of 'values', which is a major obstacle in advancing certain gender-related reforms and policies (Gościło and Holmgren 2006). The early 1990s 'abortion debate' that resulted in passing a very severe anti-abortion law in 1993 also shaped the language in a distinct way. The following words are veiled, or not used: 'pregnancy termination', 'abortion', 'foetus', 'sperm and egg', 'sexuality', 'reproductive rights', or 'women'. Instead, one hears/reads of: 'killing

\footnotetext{
${ }^{6}$ http://orka.sejm.gov.pl/proc4.nsf/uchwaly/1172_u.htm (accessed 25.08.2017).
} 
the unborn children', 'genocide' and 'murdering the unborn'; 'unborn children'; 'life'; 'creation of life'; 'motherhood'; 'blessed with a gift of giving life' / 'mothers' vs. 'murderesses'. Such discourse is not only essentially and characteristically conservative, but is spread across all political sides, from Right to Left (Szczuka 2004).

Evidently this also points the inevitability of taking into account religious morality and ethics in thinking about (Polish) sociality. While this article does not address the institution of the Catholic Church in Poland or the 'Polish' religiosity (for the two cannot be cannot be simply equated), their impact on politics of gender, sexuality, and nationality is undeniable and have been already discussed in Polish, CEE, and global contexts (c.f. among numerous others Adamczyk and Pitt 2009; Sremac and Ganzevoort 2015). In such a context, the resolution's passage about the "moral order of social life, the dignity of the family, marriage and upbringing, and the protection of life' is in fact an expression of fear of non-Catholic/non-religious values and ethical orders concerning sexualities and women's rights to reproductive control.

Additionally, Agnieszka Graff in her analysis of the major Polish weeklies from the period of around EU enlargement notices intensified 'gender talk' as an expression of anxiety about the nationhood, 'an effort to contain ambivalence about change and construct a notion of Polishness stable enough to accommodate, or perhaps even outweigh, European Union accession' (Graff 2009, 141; or see Mayer 1999; Anthias and Yuval-Davis 1989 to start with, for the broader contexts of gender and nationalisms). The 2003 Sejm's resolution is therefore an example of anxieties about the 'new era' in Polish and CEE history. Interestingly, these angsts about sovereignty of the state are rerouted through cultural values relating to bodies and identities, rather than the military, economy, or governance, which further evidences Milani’s claim that:

[w]ithout a serious engagement with the visual, the corporeal, and the affective, it is difficult to effectively unpack the dynamics of citizenship in contemporary late-modern 
conditions. In my view, it is in the mapping of the social life of affect (Ahmed 2004), and how it manifests semiotically, that there is the promise of better understanding and maybe changing - social structures and practices (Milani 2015, 330).

In the 2003 resolution, the sovereignty of the Polish nation-state was articulated through categories of (national) culture, rather than (state) institutions and citizenship. Here in the 'nation-state' compound, 'the nation' is translated into and through 'the state', where the state is made identical with the nation, political institutions with history and culture. The 'nationstate' is one of the most taken-for-granted compounds, suggesting an intrinsic connection between the two elements. A state is a spatially and geographically delimitated unit that actually, yet symbolically, demarcates the nation(s), providing boundaries, thus helping to constitute a national identity. In a sense, it could be said that a state is the materialisation of a nation, of the 'imagined community' of 'people'. However, we should be reluctant in substituting one with another, since they are not synonymous, the presumed equivalency is more than problematic (Anthias and Yuval-Davis 1989, 3). Having established the historical, cultural and political backdrop, I will now move to the analysis of the broadcast.

\section{Sequence 1: The Common Ground of the Nation}

In the first part (00:00-01:25) of his Address to the Nation, Lech Kaczyński builds a common referential ground, a mode of imagining community, with which his audience could relate and identify. This sequence operates well as an example of logics of equivalence (Laclau 1996; Laclau and Mouffe 2001), where one element is associated with the qualities of another but only vis-à-vis another self. Media play important role in creating a modern sense of 'here and now' commonality (Kopytowska 2015), which in this particular case is achieved by mobilising the 'cultural memory' of national mythologies ('Strong Independent Poland'). First of all, Kaczyński calls for the image of a threatened, but eventually victorious, nation. In the first 
sentences he suggests that Poland was under pressure from the EU, but due to the assertive and tough government, Poland has achieved control over reforms, which if unguarded, could undermine its role. Pressured to yield, the Polish government nonetheless secured the independence, and the enlisting of achievements follows: a voting system with more authoritative Polish veto; Polish proposal for the 'energy solidarity' between EU countries; or the primacy of national law above the EU. The choice of examples not only illustrates the invoked imaginary, but also the actual visual and audio clips accompanying words in the opening part of the Kaczyński's speech follow the same narrative.

The construction of the speech resembles that of news: a meticulously scripted and staged live show incorporating other pre-recorded material. Firstly, from the beginning we hear a wellknown (at least for middle and older generations) leitmotiv from the 1970s Polish television series 'Polskie Drogi' ('Polish Roads'). The series is set in the late months of WWII and narrates stories of Polish soldiers and civilians fighting against Nazi troops. Secondly, the listing of Polish achievements is accompanied by clips: of president Kaczyński being congratulated by Angela Merkel, the Chancellor of German government; two officials trying to persuade Kaczyński to do something, and his sharp and decisive gesture of 'No, I do not agree'; or a moment from the ceremonial photo shoot of the EU officials, after which one of them steps forward to Kaczyński and congratulates him. The audio-visual narrative, together with a spoken word, make a clear and unmistakable invocation of a well-known trope in the Polish national imaginary, that of oppressed Poland fighting for independence. Moreover, they introduce the image of the president and government as strong and unflinching instances of the national will. This is directly addressed in the next instance, when President Kaczyński states '[i]t pays to be unequivocal in the defence of the Polish interest'. He then mentions 67 billion Euros as an important trophy, because 'Poland is emerging from civilisation's collapse, after years of communism'. Here again a note of victimhood is played out: the current weak position of 
Poland is the fault of 'communism' (i.e. Russia and the 'West', and the post-WWII world order of Yalta agreements), hence successful EU negotiations, billions of Euros and good legal arrangements are becoming even more important, bringing added glory to the Polish president and government.

Overall, the opening part of the late president Kaczyński's speech can be understood as building 'community' for the audiences: grounded in the 'cultural memory' of well-known tropes and images (Poczykowski 2008), the president re-imagines community and re-establishes Polishness as a category 'above divisions' - a category that presumably unites the 'imagined community' into the nation (Anderson 1991). This is the moment when the music fades away, and the second part of the speech commences.

\section{Sequence 2: National Nightmares}

In the second block of the speech (01:25-03:07), viewers are presented with a simplified yet menacing message: the EU can destroy Polish culture if special protective steps are not taken against such a threat. Here, Kaczyński evokes fearful rhetoric of old national/ist nightmares, introduces the new ones, and weaves them together, lending the 'new' legitimacy of the 'old' - an aspect of the consequently deployed logics of difference and equivalence (Laclau and Mouffe 2001). It is the 'German invasion' (already evoked with the choice of the music as a leitmotiv), and 'homosexuals', treacherously as 'human rights' codified in the EU Charter of Fundamental Rights (2007). Let me unpack this entanglement of discursive shortcuts.

Firstly, we note that by the end of the first part of the speech, the camera zooms into the figure of the president, visually making him more dominant in the frame. Then, we notice the music is silenced, so the words 'But not everything in the EU must be good for Poland' sound more terrifying, forcing a spirit of importance and aggravation onto the viewers' reception of the 
speech. What follows, is a rather graphic (quite literally!) illustration and exemplification to the mindfully tactical tension built so far.

According to experts, with unpredictable decisions of the European Tribunal of Justice, some regulations of the so-called Charter of the Fundamental Rights may lead to German claims against Polish citizens, demanding restitution or compensation for property [land] left in the northern and western territories, which were granted to Poland after the WWII. (01:27-01:55)

The first menace is Germans wanting to take over Polish lands. On the visual side, the spectator watches: Angela Merkel chatting, and greeting (or congratulating) Erika Steinbach - the chair of the Federation of Expellees; the map of Germany from the 1939; and finally, the bucolic, picturesque countryside, with lakes, trees, and lush greenery. It has to be explained that Erika Steinbach became a highly controversial figure in Poland (and Germany) for her work in the 'Federation of Expellees' and insinuations that the post-WWII expulsion (or 'relocation', depending on the political standing) of Germans from the now western and northern parts of Poland due to the redrawn borders between both countries, was at least questionable. This was instantaneously picked up by the populist and nationalist groups and parties in Poland, feeding the old fears, and troubling already uneasy relations between the two countries.

The speech continues to the next example: we see Kaczyński again framed in a proud posture, the camera begins to zoom in as soon as he speaks; in a close up and more dominant onscreen, the late President warns:

Another article of the Charter, thanks to the lack of clear definition of marriage as a relation of man and woman, can threaten [literally: hit] Poland's widely accepted moral order, and force our country to introduce institutions contradicting the moral attitudes of the vast majority of the society $(01: 55-02: 16)$. 
Importantly, the words 'gay' or 'homosexuality' are not mentioned, only a vague reference to the 'institution' hostile to heteronormatively defined marriage is made. Instead, we see a clip presenting two men during their wedding ceremony. Images are more telling than words, and it seems that the President's officers in the TV studio were very mindful of persuasion and manipulation techniques, showing that verbal communication is only the tip of the iceberg, when it comes to effective ways of getting a message across.

Both examples maintain a certain degree of non-specificity and vagueness in the vocal narration, in contrast with the visual background, which is much more graphic and in your face'. This is significant, for as Rose $(2001,6)$ writes:

[...] the visual is central to the cultural construction of social life in contemporary Western societies. It is now often suggested that much meaning is conveyed by visual images. We are, of course, surrounded by different sorts of visual technologies (...) and the images they show us (...). All these different sorts of technologies and images offer views of the world; they render the world in visual terms. But this rendering, even by photographs, is never innocent. These images are never transparent windows on to the world. They interpret the world; they display it in very particular ways.

Both examples are explicitly framed as a 'threat', perilous activities and stances not only passively undermining the 'moral order' by presenting an alternative, but pro-actively destroying it, forcing itself upon society. There is a slight swing from the possible dormant threat signalled by the cautious use of 'may' in the first case of 'Germans partitioning Poland', to the more vigorous and forceful aggression suggested by the use of 'can', 'force', and 'hit' words in the case of homosexuality. Such a swing in the passivity/activity of the agency of the Others should perhaps be connected to the opening words about 'unpredictable ruling of the European Court of Justice'. In May 2007, the Court ruled that the 2005 ban on the Pride March 
in Warsaw (issued by Kaczyński himself, then Mayor of Warsaw) was illegal on three different grounds. The verdict was widely discussed in the mainstream media, and most politicians read it along the same lines as the 2006 European Parliament's resolutions about homophobia contesting it as an attack on Polish sovereignty (Kulpa 2014). Thus, the rather scornful remarks about 'unpredictable ruling', 'so-called' Charter of Fundamental Rights from the president's speech are not empty adjectives, but echo the political disdain of European Parliament's resolutions, the Court's verdict, and discussions about the Lisbon Treaty, which span the period between 2006 and 2008.

Here briefly one needs to refer to earlier context of the religious imagination, language, and Polish national identity mentioned earlier. As noted by Miłosz (1983, 117), the megalomaniac cultural narrative of Poland as the Antemurale Christianitatis dating back to the $17^{\text {th }} \mathrm{c}$. facilitated the myth of Polish Messianism, the $19^{\text {th }} \mathrm{c}$. Romantic idea of Poland as the "Christ of Nations". In conjunction with the martyrological thread in the Polish national narratives constituted vis-à-vis Prussian, Russian and Austrian empires (Walicki 1994) - the ground is ripe for both 'dangers' (Germans and homosexuals) in the presidential speech to be of a radical Otherness. They are presented as totally incomprehensible within the national framework of 'Polishness', external to the notion of Poland (spatially and culturally), and aggressively attacking boundaries, forcing themselves on Poland (victimised by implication). Moreover, they are not only a representation of Otherness, but actually inhabit a place of annihilating negativity - a total opposition, anti-Poland. In such context, the figure of the 'Anti-Christ' that comes to mind is not totally out of place here, either. Such an association is strengthened even more by the still strongly persistent association of 'Germany' with 'Nazism', and 'homosexuals' with 'death' (as presumably non-reproductive sexuality), built on the religious Catholic morality (Auer 2004). 
These references illustrate Chantal Mouffe's (2005) observations on contemporary politics, with a shifting towards the register of 'morality' and 'moralisation of politics' paradigm (although taking into account the nationalist narratives of Wester European colonial conquests, there is scope for discussion to which extent this is historical/contemporary phenomenon). Mouffe writes: '[w]hat I want to indicate is that, instead of being constructed in political terms, the 'we'/'they' opposition constitutive of politics is now constructed according to moral categories of 'good' versus 'evil'" (Mouffe 2005, 75). The negativity, nothingness of the 'evil'/'Them'/Others is also an effect (and perhaps condition) of the strategy of equivalence. Laclau and Mouffe (2001, 128-29) conclude: 'certain discursive forms, through equivalence, annul all positivity of the object and give a real existence to negativity as such. This impossibility of the real - negativity - has attained a form of presence'. In other words, it can be said that what unites elements under the equivalential umbrella of Otherness, is their negation/opposition to the discursive instance deploying the strategy of equivalence. There is nothing that the oppositional elements share among them, and the Nothing is the only '(some)thing' that they share (Torfing 1999, 124).

However, although it seems that in the dialectics of Self and Otherness, negativity is the feature of the latter, we should bear in mind that the Other is also an inevitable part of the Self. I follow here well established in cultural and nationalism studies argument that there would be no self without the Other, hence negativity haunts the Self (Bhabha 1990; W. Brown 2006; Hastings 1997; Jenkins 1996). In the analysed case, negativity troubles Polishness in its incarnations as 'people', as 'nation' and 'state', as the notions of sovereignty are performative and discursive practices, not stable constructs as they are usually seen and in which form they attempt to present themselves. In this process of performative constitution of the national self, of attaining Polishness, Kaczyński is representing one of the discourses of the nation that uses the figure of the homosexual via 'Germany' - 'traditional' incarnations of the Other in the Polish national 
narratives. Homosexuality serves as a legitimising nodal point (a branching-out point of reference in the argumentative chain) that fixes the national discourse in a momentary and fragile, temporary and never fully sustainable point. Kaczyński purges the 'nation' as floating signifier from all its complexity into the field of simplified signification, fixed on the past (oppression, struggle, independence), with new references (EU, homosexuality). A delusionary process as it is, yet necessary, for all that exists only as long as it manifests itself in the processes of becoming and separating itself from the Other.

One tentative conclusion to draw here, is an observation that in contemporary Poland, state national discourse relies (partially, but intensively) on the exclusion of the figure of the homosexual, framed as the 'threat' to the nation, to reestablish the sense of 'Polishness' that tries to find its place in the new, post-1989/2004 pan-European political realities. Importantly one should also acknowledge that the same desired 'exclusion' is also an expression of reliance on that, which is said to be 'excluded', for the act of effective 'purging' is never fully attainable. This is yet another side (although not necessary an oppositional one) of intricacies between sexual and national identities termed 'homonationalism', whereby pro-sexuality narrative is deployed as a sing of progressiveness (for an extended discussion of homonationalism concept in the CEE please see e.g. Kahlina (2015), or Kulpa (2014).

The fourth and last element of the second part of the Kaczyński's speech (after warning, firstly of Germany, and then of homosexuals) introduces calm and relaxes the tension. He promises rescue: 'Thanks to the unequivocal attitude of our delegation, we succeeded in protecting [literally: saving] Poland from these dangers'. The soothing audio leitmotiv appears anew, contributing to the idea of salvation and tranquillity after the stormy perspective. The president introduces the 'British Protocol', an appendix to the Charter of the Fundamental Rights, which makes Poland (and the United Kingdom) exempt from the Charter's binding powers in a number of issues. This protocol, as Anna Fatyga - a colleague of Kaczyński and Foreign Affairs 
MP who negotiated the Lisbon Treaty - confirmed, shelters Poland from the menacing German expellees and the homosexuals of Kaczyński's speech (Siedlecka 2007). The whole sequence performs towards schemata described by Goussios et al. $(2014,175)$ in relation to the US presidential rhetoric on the 'War on Terror': "(f)ear rhetoric does not leave public opinion with any options other than to follow the president. He [the president] knows the extent of the threat and is the only one who can deal with it. He has restored his ethos and will manage the crisis".

\section{Dislocation and Social Antagonism}

So far, the National Address of the former president is constructed in terms of a battle, a war even, between 'good', National, Polish, and 'evil' European forces. Each side is presented as an enemy and the antagonism seems irresolvable, since the two instances are polarised to their extremes, and no common ground is envisaged. Such discursive moves are perhaps one of the most basic practices observable in politics generally, according to Chantal Mouffe. The antagonistic conflict cannot be overcome nor addressed as long as it remains in the register of 'antagonism' and not 'agonism'. She writes that while antagonism is a relation of two enemy positions without common ground (and with denial of the other side), agonism however, is when both sides recognise the right of the other party to have different standing grounds: '[t]hey are 'adversaries' not enemies' thus allowing for possibility of change (Mouffe 2005, 20). The presidential discourse however conserves and stabilises the conflict as the default modus operandi, disallowing any form of rapprochement.

Germany, the 'old' enemy in the 'Traditional Polishness' narrative is coupled in the early 2000s with homosexuals, a 'new' enemy. The representation of the social situation and advances onto the European arena are presented as a battleground because it helps, in my opinion, to reconstitute the notion of 'here and now' of the national narrative. Finding known patterns and themes of victim, oppression, saviour, and victory in times of 'transformation', dislocation and 
instability - helps to make sense of reality. Kaczyński’s National Address attempts to reestablish (national) identities by unfolding strategies of equivalence: discursively re-creating the Other, which would re-constitute the boundaries of the nation after the moment of dislocation ('regained' freedom in 1989, and the EU accession in 2004). Importantly, it is no longer only the Other nations (Germany or Russia, or Jews) but the homosexual as the 'constitutive outside', to use Laclau's terminology (Laclau 1990, 17). Equivalence operates on the basis of metonymical resemblance, by association. Wendy Brown (2010) underlines that metonymy is an indispensable element of nationalism, so what we observe in the Kaczyński's speech, is that it is the homosexual that is crucially counter posed to the national, and metonymically framed as the contemporary Other of the Polish nationhood that emerges at the brink of the $21 \mathrm{st}$ century.

Much of these processes are outcomes of 'dislocation', to remain within the Mouffe and Laclau's conceptual framework. Dislocation occurs when one or more events/occurrences destabilize the present regime. In consequence, the existing 'floating signifiers' must be rearticulated anew to fit the changed discursive order. The game to reroot the dislocated identities in the new, emerging forms of sociality is on (Torfing 1999, 195). In this sense, '1989' and '2004', as symbolic representations of the series of changes, are without doubt major examples of 'dislocation'. Social, cultural, and economic conditions of living have changed for people in Poland and CEE, as did rules and mechanism of the political games, centres and holders of (political, economic, and social) power(s). 1989/2004 conceived as dislocation is possible because the nation (and the EU for that matter) is more an 'imagined community' rather than any remotely homogenous group; also because a state is to be understood as a set of practices or 'ensemble of practices' rather than a 'thing' (Finlayson and Martin 2006, 155).

'Poland' thus denotes a set of practices of people relating to each other in a given group and circumstances. How these relations are (per)formed after 1989 (and later after 2004 - the year 
Poland joined the EU) cannot be predicted anymore only on the basis of traditional indicators of national bonding/binding. Kaczyński seems to be aware of that, hence his insistence on introducing 'new' threats rerouted via the 'old' ones. One of the outcomes of dislocation is social antagonism, which signifies and constitutes the limit of the 'social'. Social antagonism occurs because sociality (i.e. discursively created identities of subjects) is lacking what is expelled and wasted, hence foreclosing the possibility of 'fullness'. Social agents are unable to attain their 'whole identities', as there is, accordingly, always a remainder, a bit of 'waste' left behind; The Other, which must become an enemy. For it reminds the Self of its incompleteness, it is the one to be blamed for the subject's own 'failure' in identification (Laclau and Mouffe 2001, 125). In this sense identities and antagonisms show the limits of a 'social' (national), its instability and vulnerability, and Kaczyński's speech is an excellent exemplification of these tensions.

\section{Spaced Out Cartography}

Spatial dimensions are often taken for granted, in the sense that geography and location are treated as 'real' and not problematized as possible discursive formations (as are 'sovereignty', 'state', and 'nation'). In relation gender and sexuality, such spatial categories as 'boundaries', 'liminality', 'enclosure' and 'openings' 'here and there' are asking for more scrutiny and attention, point well-argued by critical geographers (e.g. G. Brown and Browne 2016) And also important in reflection on the formation of sexualities in CEE, as the debates remain in a tight relation to, and under the immense influence of the contemporary 'Western' imaginaries and hegemonies (Kulpa and Mizielinska 2011). This, in consequence, directly relates to the way national/istic discourses frame homosexuality in their discourses, often in direct response to the 'Western' and specifically the EUropean influences (Kahlina 2015). 
In Kaczyński's speech, the dialectics of we/they, here/there, inside/outside prompt us to think about place and location as crucial tropes in his presentation. So does the strategic use of maps as a visual prompt and an act of creating meanings (cf. Rose 2001, quoted above). While the first 'danger' of losing land for the benefit of Germans is introduced, spectators are presented with a map of Europe form circa 1939 (01:46). This not only helps to visualise the possible threat, but actually embodies the menace, mapping it out in the form of Nazism (for the map represents Nazi Germany and illustrates its geopolitical aspirations). As Kalenda and Krager (2016) write, the references to the World War I and II are not unusual in the political speeches of the CEE presidents. And so Kaczyński not only brings flesh to the idea of the German threat, but is using it as a metaphorical representation of not only the 'German threat', but a particular incarnation of it: Nazism. The map then becomes a tool in the warfare discourse of Kaczyński, a means of conveying messages, as much as forcing a particular political agenda. The map from Kaczyński’s speech visualises borders and boundaries, some of which after 2004 quite literally disappeared. The so-called 'Schengen Agreements' (1985) regulate free movement within most of the EU countries, effectively tearing down national / state borders. In the president's discursive creation, this is not however a fact worthy of celebration, but rather a significant reminder that with the EU there is nothing separating Germany and Poland. The EU is blurring already porous borders/boundaries between the peoples even more. Kaczyński's insistence on mapped out borders shows how physical borders of fences, walls, check points, etc. are dependent on discursive (and thus, perhaps more elusive and harder to conceive as real) practises bringing boundaries into life. The discursive erection and maintenance of borders between 'good' and 'evil', Poland and Germany, and assumed heterosexuals and homosexuals, is an act of political governance organising social space according to a particular ideological perspective. In the attempt to dominate 'the national' (an example of the empty, universal signifier in Laclau and Mouffe's framework), Kaczyński needs maps and boundaries to perform 
effectively the elimination of the 'constitutive outside' (EU/Germany/homosexual), and finally - to gain some sense of national identity. However, Wendy Brown (2010) suggests that walls (for she is working on 'walls' as symbolic and actual expression of states and sovereignty) project an image of the nation-state's sovereignty, which does not exist otherwise; walls stage sovereignty. She makes clear that this projection is not only performed for Others, outside the boundaries. Staging is also, if not at times especially, done for the people of the nation within those walls. In this sense, the use of the map in Kaczyński's speech is an act of such internal projection; maps, as walls, perform re-closure of the nation from within.

\section{Sequence 3: Enemy Within}

Thinking about the dialectics of inside/outside, us/them - we also should ponder the possibility of the (already) existing threat within the bordered 'us' territory, not only the external Others. The figure of the 'enemy within' is as 'popular' as its brotherly equivalent, the 'enemy outside' in national discourses. While each country/nation have their own history of such othering, in Polish case such an 'enemy within' position has often hitherto been occupied by Jews. Since the end of WWII and the communist purges in 1968, the Jewish minority in Poland has existed only as a tiny fraction of the population. What seems to be happening at the beginning of the 21 st century, is the national imposition of the figure of the homosexual as a modern day 'enemy within' (cf. similarities on such 'lavender menace' discussed in e.g. Moss and Simić 2011). Perhaps because of this shared 'location' some activists and critics imply that we can draw parallels and think of 'homophobia as the $21^{\text {st }}$ c. anti-Semitism' (Ostolski 2007; also: Szulc 2017, 186-87), an alluring analogy, which nonetheless requests more scrutiny on another occasion.

The figure of the 'enemy within' is introduced in the Kaczyński's speech as the third component (03:08-04:15). After the soothing information about securing the national interests by signing 
the 'British Protocol' (end of the second part), the former president returns to his alarmist tone. Although the document would stabilise and enforce the position of Poland in Europe, the 'current government' (that of Civic Platform that came to power after the defeat of the president's own Law and Justice party) extremely quickly ('a week later') expressed the will to opt-out of the 'British Protocol' and sign the Lisbon Treaty unconditionally. Framed as the treacherous act of acceding the nation to the evil forces of the EU, it cannot be accepted by the president. As the head of the state, securing its sovereignty and independence, he needs to act, to strike back against the act of treason. He implies that giving up on the 'British Protocol' is an act of yielding on the vital interests of the nation. It is to be defeated in this warfare of the Poland and the EU. 'The current government's' decision is a sign of its weakness, but also of the clout and strength of the threatening powers. Unintentionally, Kaczyński confirms that the national discourse can never be secure of itself, that the Other will always be a menacing presence on the national horizon. Moreover, the menace of the EU, coming from the outside has already found its accomplices within the body of the nation - the nation is already contaminated, driven by the disease of homosexuality (in disguise of the 'human rights'). And it must be a powerful one, since it reaches the highest state officials - the government.

What we see in the third part of the speech is the return to the defensive positions in the state narrative, and pluralisation of 'dangers' located on the both sides of the imagined borders. (In itself, another example of permanent permeability of borders, unconsciously and unwillingly slipping over the discursive practices that claim otherwise.) Homosexual desire, since it is not geographically bound (as 'Germany' or the 'EU') is largely metaphorical, but can also be seen as a very real agent operating across the boundaries, one that cannot be confined and enclosed by the physical borders; it is the syndrome, cause, and effect of the borderlessness in which the nationhood is diluting itself. Hence the former president's attempts at re-creating and reestablishing boundaries that would constitute the identity of the national and the Other selves. 
However, it seems that the very logic of dialectical opposition that polarises and is meant to crystallise those identities (cf. mentioned Mouffe's 'agonism/antagonism'), is also the very logic of the impossibility of pure identity and opposition. The limits of the discursive invocations, physical and geographical demarcations are porous and unachievable, yet necessary for they form the imaginary object of desire and constant struggle for - a goal that spins the perpetual machinery of identifications and locations, of 'East' and 'West', of nationhood, and the construction of homosexuality, Poland and the EU.

\section{Conclusions: Selfless Otherness}

In Lech Kaczyński's 'Address to the Nation' speech, a process of re-creating identities and reimagining politics emerged as an important discursive practice. The dynamic between the national discourse and the constructed homosexual figure as 'threat' is mediated by the set of other categories, like state ('Germany', 'EU', 'Poland'), geography ('Western Europe', 'CEE'), history and culture ('East' and 'West'). Released at the moment of social dislocation within the EU as a whole and within its member states individually (2004 enlargement of the thus far mostly Western European club onto South-Eastern Europe), the weaving of the political and cultural seems particularly important in the first decade of the $21^{\text {st }}$ century. It is so, because it was an intense moment of the cultural rewriting of 'European identity', culminating with the failed attempt to consolidate it in a single (political) document ('EU constitution'). Instead the Lisbon Treaty has been passed, which in turn became a focal point of reference for the Polish president in his narrative strategy of reconstituting the national identity in this new postcommunist, pan-European, reality.

I believe it is also a crucial moment for understanding at least two more recent (2016/7) political games. The first being around Polish public media broadcasters, and includes symbolic and figurative practices of personnel purges and institutional renaming at the order of the ruling 
Law and Justice party (Kublik 2016). The second relating to the 'anti-gender' campaigning, whereby conservative and religious authorities wage a war against what they call 'gender ideology' of secular, liberal values (i.e. LGBT rights) (Graff and Korolczuk 2017; Kuhar and Paternotte 2017).

And as the political and media collide together over the national identity, borders and porousness play more significant role as tools and strategies of reframing new 'cultural memories' and Polish national identities (Poczykowski 2008). However, such 'walling' of inside Self, against the Other outside, functions more like a mirror and remainder, rather than an act of disposal. The discourses of nation and homosexuality, more than anything else, are inevitable and haunting mirror images of each other; the Double. 'Polishness' as a certain set of identityoriented factors and conditions, may only exist as a 'process towards' itself (that is 'Free Poland'), since the achievement of its fullness is the Impossible: aporia, a self-mutilation. Therefore, after 1989, and especially after 2004 and around the 2007's the Treaty of Lisbon, the relations between Poland and the European Union are sites where we can observe the discursive re-formulations of meanings, priorities, and signifiers. Homosexuality then becomes a 'constitutive outside' for the modern national imaginary in Poland, as performed in the state discourse of the Presidential 'Address to the Nation'. Fundamental/radical outside constitutes and at the same time negates the thin lines of 'identity' (here national), from which it is excluded. Homosexuality as a constitutive outside becomes a fixative nodal point of national/ist discourse, temporarily hooking the meaning of sovereignty (Polishness) at the moment of antagonistic dislocation in the national narrative and history (the 1989 'epiphany of freedom' and the 2004 'return to Europe'). However, this is never a fully accomplished act, and can only be envisaged as the process of fixing, establishing, holding, etc., always expressed in the grammatical form of a gerund. 


\section{References}

Adamczyk, Amy, and Cassady Pitt. 2009. 'Shaping Attitudes About Homosexuality: The Role of Religion and Cultural Context'. Social Science Research 38 (2): 338-51. https://doi.org/10.1016/j.ssresearch.2009.01.002.

Andersen, Niels Åkerstrøm. 2003. Discursive Analytical Strategies: Understanding Foucault, Koselleck, Laclau, Luhmann. 1st ed. Bristol: The Policy Press. https://doi.org/10.2307/j.ctt1t898nd.

Anderson, Benedict. 1991. Imagined Communities: Reflections on the Origin and Spread of Nationalism. 2nd ed. Verso Books.

Anthias, Floya, and Nira Yuval-Davis, eds. 1989. Woman - Nation - State. Basingstoke: Macmillan.

Auer, Stefan. 2004. 'Nationalism in Poland'. In Liberal Nationalism in Central Europe. London-New York: Routledge.

Barrington, Lowell W, ed. 2006. After Independence: Making and Protecting the Nation in Postcolonial and Postcommunist States. Ann Arbor: University of Michigan Press.

Berger, Arthur Asa. 2016. Media and Communication Research Methods: An Introduction to Qualitative and Quantitative Approaches. Los Angeles: SAGE.

Bhabha, Homi, ed. 1990. Nation and Narration. London: Routledge.

Brown, Gavin, and Kath Browne, eds. 2016. The Routledge Research Companion to Geographies of Sex and Sexualities. London - New York: Routledge.

Brown, Wendy. 2006. Regulating Aversion: Tolerance in the Age of Identity and Empire. Princeton: Princeton University Press.

--- . 2010. Walled States, Waning Sovereignty. New York: Zone.

Cap, Piotr. 2017. 'From "Cultural Unbelonging" to "Terrorist Risk": Communicating Threat in the Polish Anti-Immigration Discourse'. Critical Discourse Studies 0 (0): 1-18. https://doi.org/10.1080/17405904.2017.1405050.

Chołodowski, Maciej. 2017. 'Wpływy Pis Na Wizji I W Eterze. Nowe Rady Mediów Narodowych'. Gazeta Wyborcza, 24 January 2017, gazeta.pl edition.

Denzin, Norman K., and Yvonna S. Lincoln, eds. 2005. The SAGE Handbook of Qualitative Research. 3rd ed. London: SAGE.

Downing, Lisa, and Robert Gillett, eds. 2011. Queer in Europe: Contemporary Case Studies. Farnham: Ashgate.

Eshbaugh-Soha, Matthew. 2010. 'The Politics of Presidential Speeches'. Congress \& the Presidency 37 (1): 1-21. https://doi.org/10.1080/07343460903390679.

Finlayson, Alan, and James Martin. 2006. 'Poststructuralism'. In The State: Theories and Issues, edited by Colin Hay, Michael Lister, and David Marsh. Basingstoke: Palgrave Macmillan.

gazeta.pl. 2008. 'Spot, Szopka, Teledysk - Oceny Orędzia Prezydenta'. Gazeta.PI, 18 March 2008, Online edition. http://wiadomosci.gazeta.pl/wiadomosci/1,114873,5033511.html.

Gościło, Helena, and Beth Holmgren, eds. 2006. Poles Apart: Women in Modern Polish Culture. Bloomington, Ind: Slavica Publishers.

Goussios, Charalampos, Neofytos Aspriadis, Zoi Tsirimiagou, and Myrsini Dogani. 2014. 'Rhetorical Use of Fear in Presidential Speeches: The War on Terror Discourse'. Journal of Arab \& Muslim Media Research 7 (2-3): 163-83. https://doi.org/10.1386/jammr.7.2-3.163_1.

Graff, Agnieszka. 2009. 'Gender, Sexuality, and Nation - Here and Now: Reflections on the Gendered and Sexualized Aspects of Contemporary Polish Nationalism'. In Intimate Citizenships: Gender, Sexualities, Politics, edited by Elżbieta Oleksy. New York: Routledge.

Graff, Agnieszka, and Elżbieta Korolczuk. 2017. "'Worse than Communism and Nazism Put Together": War on Gender in Poland'. In Anti-Gender Campaigns in Europe: Mobilizing Against Equality, edited by Roman Kuhar and David Paternotte, 175-94. London ; New York: Rowman \& Littlefield. 
Hall, Dorota. 2017. 'Religion and Homosexuality in the Public Domain: Polish Debates About Reparative Therapy'. European Societies Online First (June): 1-23. https://doi.org/10.1080/14616696.2017.1334947.

Hastings, Adrian. 1997. The Construction of Nationhood: Ethnicity, Religion and Nationalism. Cambridge: Cambridge University Press.

Hayes, Jarrod. 2000. Queer Nations: Marginal Sexualities in the Maghreb. Chicago, III: University of Chicago Press.

Henderson, Tim. 2006. 'Introducing Emotion: The Use of Emotion and Character in Presidential Speeches'. Elements 2 (1). http://ejournals.bc.edu/ojs/index.php/elements/article/view/8939.

Jenkins, Richard. 1996. Social Identity. London: Routledge.

Kahlina, Katja. 2015. 'Local Histories, European LGBT Designs: Sexual Citizenship, Nationalism, and "Europeanisation" in Post-Yugoslav Croatia and Serbia'. Women's Studies International Forum 49: 73-83. https://doi.org/10.1016/j.wsif.2014.07.006.

Kalenda, Jan, and Tomáš Karger. 2016. 'Political Memory and Symbolic Boundaries: Czech Presidential Speeches After 1989'. International Journal of Media \& Cultural Politics 12 (1): 43-58. https://doi.org/10.1386/macp.12.1.43_1.

Kopytowska, Monika. 2015. 'Ideology of "Here and Now"'”'. Critical Discourse Studies 12 (3): 347-65. https://doi.org/10.1080/17405904.2015.1013485.

Krzyżanowski, Michał, and Per Ledin. 2017. 'Uncivility on the Web. Populism in/and the Borderline Discourses of Exclusion'. Journal of Language and Politics 16 (4): 566-81. https://doi.org/10.1075/jlp.17028.krz.

Kublik, Agnieszka. 2015. 'Koniec z "bolszewizmem" w Telewizji i Radiu Publicznym: Narodowe Media PiS'. Gazeta Wyborcza, 9 December 2015, wyborcza.pl edition. http://wyborcza.pl/1,75968,19314872,koniec-z-bolszewizmem-w-telewizji-i-radiupublicznym-narodowe.html.

- - - 2016. 'Media Publiczne. Wielka Czystka w Radiu i TV PiS'. Gazeta Wyborcza, 18 May 2016, wyborcza.biz edition. http://wyborcza.pl/politykaekstra/1,132907,20091853,media-publicznewielka-czystka-w-radiu-i-tv-pis.html.

Kuhar, Roman, and David Paternotte, eds. 2017. Anti-Gender Campaigns in Europe: Mobilizing Against Equality. London; New York: Rowman \& Littlefield International, Ltd.

Kulpa, Robert. 2014. 'Western Leveraged Pedagogy of Central and Eastern Europe: Discourses of Homophobia, Tolerance, and Nationhood'. Gender, Place \& Culture 21 (4): 431-48. https://doi.org/10.1080/0966369X.2013.793656.

Kulpa, Robert, and Joanna Mizielinska, eds. 2011. De-Centring Western Sexualities: Central and Eastern European Perspectives. Farnham: Ashgate.

Laclau, Ernesto. 1990. New Reflections on the Revolution of Our Time. London: Verso.

-- - 1996. Emancipation(S). New York: Verso.

- - . 2005. On Populist Reason. London: Verso.

Laclau, Ernesto, and Chantal Mouffe. 2001. Hegemony and Socialist Strategy: Towards a Radical Democratic Politics. 2Rev Ed. London: Verso.

Lu, Louis Wei-Lun, and Kathleen Ahrens. 2008. 'Ideological Influence on BUILDING Metaphors in Taiwanese Presidential Speeches'. Discourse \& Society 19 (3): 383-408. https://doi.org/10.1177/0957926508088966.

Mayer, Tamar. 1999. 'Gender Ironies of Nationalism: Setting the Stage'. In Gender Ironies of Nationalism: Sexing the Nation, edited by Tamar Mayer, 372. London: Routledge.

Milani, Tommaso. 2015. 'Language and Citizenship: Broadening the Agenda'. Journal of Language and Politics 14 (3): 319-34. https://doi.org/10.1075/jlp.14.3.01mil.

Miłosz, Czesław. 1983. The History of Polish Literature. Los Angeles: University of California Press.

Moss, Kevin, and Mima Simić. 2011. 'Post-Communist Lavender Menace: Lesbians in Mainstream East European Film'. Journal of Lesbian Studies 15 (3): 271-83.

https://doi.org/10.1080/10894160.2011.530143.

Mouffe, Chantal. 2005. On the Political. London: Routledge. 
Ostolski, Adam. 2007. 'Spiskowcy i Gorszyciele. Judaizowanie Gejów w Polskim Dyskursie Prawicowym'. In Jak Się Dzielimy i Co Nas Łaczy? Przemiany Wartości i Więzi We Wspótczesnym Społeczeństwie Polskim, edited by Małgorzata Głowacka-Grajper and Ewa Nowicka. Kraków: Zakład Wydawniczy 'Nomos'.

Parker, Andrew, Mary Russo, Doris Sommer, and Patricia Yaeger, eds. 1992. Nationalisms \& Sexualities. London; New York: Routledge.

Pink, Sarah, László Kürti, and Ana Isabel Afonso, eds. 2004. Working Images: Visual Research and Representation in Ethnography. London; New York: Routledge.

Poczykowski, Radoslaw. 2008. 'Building the Past, Forgetting the Future: Is Poland a Historical Knowledge Based Society?' LIMES: Cultural Regionalistics 1 (1): 22-31. https://doi.org/10.3846/2029-0187.2008.1.22-31.

Rose, Gillian. 2001. Visual Methodologies: An Introduction to the Interpretation of Visual Materials. London; Thousand Oaks, Calif.: Sage.

Ryazanova-Clarke, Lara. 2008. 'Re-Creation of the Nation: Orthodox and Heterodox Discourses in PostSoviet Russia'. Scando-Slavica 54 (1): 223-39. https://doi.org/10.1080/00806760802494307.

Shiraev, Eric, and Vladimir Shlapentokh, eds. 2002. Fears in Post-Communist Society. London: Palgrave Macmillan.

Siedlecka, Ewa. 2007. 'Karta Praw to Nie Rozbiory'. Gazeta Wyborcza, 28 October 2007, gazeta.pl edition. http://wyborcza.pl/1,86649,4614479.html.

Smith, Anna Marie. 1998. Laclau and Mouffe: The Radical Democratic Imaginary. London: Routledge.

Sremac, Srdjan, and R. Ruard Ganzevoort, eds. 2015. Religious and Sexual Nationalisms in Central and Eastern Europe: Gods, Gays and Governments. Amsterdam: Brill. https://doi.org/10.1163/9789004297791.

Stychin, Carl. 1998. A Nation by Rights: National Cultures, Sexual Identity Politics, and the Discourse of Rights. Philadelphia: Temple University Press.

Szczuka, Kazimiera. 2004. Milczenie Owieczek: Rzecz o Aborcji. Warszawa: W.A.B.

Szulc, Lukasz. 2017. Transnational Homosexuals in Communist Poland. London: Palgrave Macmillan. https://doi.org/10.1007/978-3-319-58901-5.

Torfing, Jacob. 1999. New Theories of Discourse: Laclau, Mouffe, and Zizek. Oxford: Blackwell.

Walicki, Andrzej. 1994. Poland Between East and West: The Controversies Over Self-Definition and Modernization in Partitioned Poland. Cambridge, Mass: Ukranian Research Institute, Harvard University.

Wodak, Ruth. 2015. The Politics of Fear. What Right-Wing Populist Discourses Mean. Los Angeles: Sage.

Yin, Robert K. 2009. Case Study Research: Design and Methods. 4th ed. Los Angeles, CA.; London: Sage. 